\title{
Menstrual Suppression Practice among Female Malaysian Pilgrims
}

\author{
Rafidah $\mathrm{MR}^{\mathrm{a}}$, Zuhra $\mathrm{H}^{\mathrm{b}}$, Harlina Halizah $\mathrm{S}^{\mathrm{c}}$, Azah $\mathrm{AS}^{\mathrm{d}}$, Tan $\mathrm{CE}^{\mathrm{b}}$ \\ ${ }^{a}$ Setapak Health Center ( Ministry of Health) , Kuala Lumpur, Malaysia. \\ ${ }^{b}$ Department of Family Medicine, Faculty of Medicine, Universiti Kebangsaan Malaysia Medical Center, Jalan Yaacob Latiff, Kuala \\ Lumpur, Malaysia \\ 'Department of Medical Education, Faculty of Medicine, Universiti Kebangsaan Malaysia Medical Center, Jalan Yaacob Latiff, Kuala \\ Lumpur, Malaysia. \\ ${ }^{d}$ Shah Alam Seksyen 7 Health Clinic (Ministry of Health, Malaysia), Selangor, Malaysia
}

\section{ABSTRACT}

INTRODUCTION: Performing the Hajj or pilgrimage is obligatory for all Muslims. Certain Hajj religious rites cannot be performed during menstruation. Hence, it is common for female pilgrims to seek a doctor's advice on methods of menstrual suppression during Hajj. This exploratory study aimed to determine the prevalence and usage profile of menstrual suppression practices among Malaysian women performing Hajj and their associated factors. MATERIALS AND METHODS: An observational cohort study involved 437 women aged 18-55 years old who attended compulsory pre-Hajj courses in Klang Valley, Malaysia. The self-administered questionnaires contained sociodemographic information, and biomedical characteristics were obtained. A follow-up call was made after their return from Hajj to obtain information regarding practice, medication is taken, and their intended duration of menstrual suppression. Descriptive and inferential analysis were done. RESULTS: Post Haji, about 81.3\% (347/437) of women were contactable and completed their menstrual calendar and 17.6\% (62/347) of female pilgrims practiced menstrual suppression. The mean duration of hajj was 44 days and $77.4 \%$ (48/61) intended to suppress their menstruation throughout the whole of their Hajj travel. Previous use of contraception was associated with menstrual suppression practice $(\mathrm{p}<0.001)$. The commonest method of menstrual suppression was combined oral contraceptive pills (53.2\%) followed by oral progestogens only pill (35.5\%). CONCLUSION: Almost one-fifth of Malaysian female Hajj pilgrims practiced menstrual suppression. Previous use of contraception was associated with menstrual suppression practice. Combined oral contraceptive pills were the commonest method used and the method was chosen was based on the individual desired duration of menstrual suppression.

KEYWORDS: women, female, pilgrimage, menstrual suppression, Hajj,

\section{INTRODUCTION}

Performing the Hajj or pilgrimage to Mecca at least once in a lifetime is one of the pillars of Islam which is compulsory for all Muslims. Women in their reproductive age group make up about one-quarter of Hajj pilgrims. During menstruation, women are

\section{Corresponding Author:}

Dr. Zuhra Hamzah

Department of Family Medicine, Level 14,

Pra-Clinical Block, Faculty of Medicine,

Universiti Kebangsaan Malaysia Medical Center,

Jalan Yaacob Latiff, 56000 Cheras,

Kuala Lumpur, Malaysia.

Tel No: +603-91459456

Email: zuhradr@ppukm.ukm.edu.my forbidden to pray, fast, touch, and embrace the Quran, sit in the mosque, circumambulate (tawaf), and cannot be divorced.1,2,3 Circumambulation is one of the pillars of the pilgrimage and it is a compulsory element for every pilgrim. Some female pilgrims may prefer to suppress their menses during Hajj to allow them to complete their religious rites within the limited time given.

Menstrual suppression is defined as "manipulation of monthly menstruation using hormonal medications".4 In general, women practice menstrual suppression for various reasons such as to alleviate troublesome symptoms 4,5 and to control the timing of menstruation 
for important events. ${ }^{6,7}$ Menstrual suppression was practised among undergraduate students ${ }^{8}$ and in India during the fasting month of Ramadhan. ${ }^{9}$

There are various religious opinions on the use of menstrual pills. Al-Imam al-Bahuuti al-Hanbali Rahimahullah had stated that it is permissible to take medicine to suppress menstruation provided they do not cause harm. ${ }^{10}$ Some argue that menstrual suppression is not necessary during Hajj, as only certain religious rites of Hajj, which is 'tawaf', cannot be performed during menstruation; therefore, women can wait until they are clean before performing 'tawaf.'11 However, the opportunity to perform Hajj maybe only once in a lifetime event for many, because of its high cost and a limited annual quota of pilgrims per country set by the Saudi Arabian government. ${ }^{12}$ The issue of menstrual suppression using medication by female pilgrims was discussed in the Malaysian 33rd (2016) National Muzakarah Hajj. ${ }^{13}$ Female pilgrims are allowed to use menstrual pills to prevent or to shorten the duration of menstruation to allow them the opportunity to worship during the hajj (especially during Masya'ir: the most important phase of hajj. However, they are encouraged to consult and to follow all instructions given by the doctor to avoid menstrual problems. ${ }^{13,14}$

There are many methods of suppressing or delaying menses.5,15,16 The choice of methods should be individualised depending on their necessity, medical history, side effect profiles of the options, and woman's preference.

Most female Hajj pilgrims require only short-term menstrual suppression during the 1-2 months Hajj period. There are currently no guidelines for healthcare providers regarding the selection of methods of menstrual suppression. Due to the lack of evidence and guidelines, physicians are often left to prescribe medications based on their judgement and clinical experience.

There was extremely limited literature documenting the practice of menstrual suppression among female Hajj pilgrims. To the best of our knowledge, only one study among 116 female Nigerian pilgrims ${ }^{17}$ was done, where $16.7 \%$ practiced menstrual suppression. Their practice was found to be associated with their occupation and IMJM Volume 20 No.1, Jan 2021 previous use of contraception. Interestingly, awareness about the availability of menstrual suppression options did not influence their practice.

This exploratory study is therefore intended to determine the prevalence of menstrual suppression practice among Malaysian female Hajj pilgrims, its usage profile, and associated factors. This paper will provide much-needed baseline data for future research in this field, and guide female pilgrims and doctors in decisionmaking.

\section{MATERIAL \& METHODOLOGY}

This study was part of an observational cohort study conducted from May 2014 to December 2015. Data collection was done after obtaining ethical approval from the Institutional Ethics Committee (FF-2014-240), and the Ministry of Health Medical Research and Ethics Committee (NMRR ID No: NMRR-14-545-21311). Permission to conduct the study was also granted by Lembaga Tabung Haji (LTH) or Pilgrim's Management Fund Board. We studied all female pilgrims who were scheduled for their Hajj pilgrimage with LTH in 2014 with regular menstrual cycles. The recruitment was from the compulsory pre-Hajj intensive courses organised by LTH at 4 different venues in Kuala Lumpur. Pregnant women and women with menstrual irregularities due to known gynaecological pathology were excluded from the study.

\section{STUDY INSTRUMENTS}

A data collection form comprising of 6 parts and a menstrual calendar was used. They were comprised of :

Part 1: Socio-demographic information and contact details

Part 2: Hajj itinerary and travel information

Part 3: Basic medical or surgical history

Part 4: Gynaecological history

Part 5: Contraceptive history

Part 6: Menstrual Suppression Practice

The data collection form was pre-tested among 10 women attending a public health clinic to ensure clarity and comprehensibility. Amendments were done based on the pre-test feedback. The revised data collection 
form underwent a further 2 rounds of pre-testing and amendments before it was deemed satisfactory.

\section{DATA COLLECTION}

The recruitment of the study subjects was done during compulsory 2-day intensive preparatory pre-Hajj courses organized by LTH in Kuala Lumpur. Pilgrims who have been offered to perform their Hajj pilgrimage in the year 2014 had to attend these courses at the nearest designated course locations. These courses were carried out in batches of about 150-200 pilgrim candidates each. During the pre-Hajj intensive courses, a brief explanation of the study was given to all women. Women who agreed to be enrolled in the study and fulfilled the inclusion criteria were given informed consent and were asked to fill up the Part 1 to Part 5 forms which were returned to the researcher on the same day. The part 6 form was kept by the respondents and returned to the researcher via mail after Hajj. The respondents who failed to mail the form were contacted via telephone to gather information regarding whether they had practiced menstrual suppression, medications are taken and their intended duration of menstrual suppression.

Since this was an exploratory observational study, respondents were free to choose whether to practice menstrual suppression during Hajj, to consult any doctors, and to decide on the preferred menstrual suppression methods. The researcher did not make any suggestions or prescriptions during recruitment.

\section{STATISTIC}

Data was entered into the IBM Statistical Package for Social Science (SPSS) software version 21.0 for statistical analysis. Descriptive statistics for categorical data were described as frequencies and percentages, while continuous data, which were normally distributed, were described as means and standard deviations. Inferential analyses were conducted using Pearson Chi-square or Fisher Exact test for categorical data, and Student t-test for normally distributed continuous data.

The dependent variable in this study was the practice of menstrual suppression. The independent variables were the socio-demographic variables and clinical characteristics.

\section{RESULTS}

A total of 427 eligible respondents returned their respondents' information sheet during the study period. Seventy-five women $(17.6 \%)$ were excluded from the analysis due to various reasons, giving a completion rate of $81.3 \%(\mathrm{~N}=347)$.

\section{Baseline characteristics of study participants}

The mean age of participants was $42.00 \pm 0.34$ years old which indicates most of the female pilgrims were in their reproductive age. Most of them were Malays (99.4\%) and the other $2(0.6 \%)$ were Bumiputera from Sabah/ Sarawak. They had attained tertiary education (73.8\%). Around half had a history of contraceptive use in the past $(47.6 \%)$. The mean duration of Hajj was 44.00 $( \pm 5.40)$ days. (Refer to Table I)

\section{The prevalence and profile of menstrual suppression practice during Hajj among women pilgrim}

The prevalence of menstrual suppression practice during Hajj among this cohort of female Haji pilgrims was found to be $17.6 \%$. (Refer to Table I)

About half of the women used COCP for menstrual suppression $(42 \%$ used COCP containing 30 micrograms Ethinylestradiol, $11 \%$ used COCP containing 20 micrograms Ethinylestradiol). Oral progestogens $(35.5 \%)$ were the second most popular choice, followed by intramuscular Depo Provera (4.8\%). Antifibrinolytics such as tranexamic acid (1.6\%) and non -steroidal anti-inflammatory drugs mefenamic acid $(4.8 \%)$ were less prescribed. (Refer to Table II)

\section{Intended Duration For Menstrual Suppression Practice}

Among those who practiced menstrual suppression, all women who took COCP intended to achieve total amenorrhea throughout Hajj duration, whereas in the oral progestogen group, half of them (54.5\%) intended 
for total amenorrhoea while another $45.5 \%$ intended to delay menses over a short duration. (Refer to Table III)

Table I: Selected sociodemographic, medical characteristics and profile of menstrual suppression practice among female Hajj participants. $(\mathrm{N}=347)$

\begin{tabular}{|c|c|c|c|c|}
\hline \multicolumn{2}{|l|}{ Variables } & \multirow[t]{2}{*}{ Mean (SD) } & \multicolumn{2}{|c|}{$\mathrm{N}=347$} \\
\hline & & & $\mathrm{n}$ & $(\%)$ \\
\hline Age (years) & & $42.00(0.34)$ & & \\
\hline \multirow[t]{2}{*}{ Race } & Malay & & 345 & 99.4 \\
\hline & Others & & 2 & 0.6 \\
\hline \multirow{3}{*}{$\begin{array}{l}\text { Level of } \\
\text { cations }\end{array}$} & Primary & & 8 & 2.3 \\
\hline & Secondary & & 83 & 23.9 \\
\hline & Tertiary & & 256 & 73.8 \\
\hline \multirow[t]{6}{*}{ Occupations } & Government & & 121 & 34.9 \\
\hline & Private & & 107 & 30.8 \\
\hline & Self employed & & 13 & 3.7 \\
\hline & Home maker & & 96 & 27.7 \\
\hline & Retiree & & 1 & 0.3 \\
\hline & students & & 9 & 2.6 \\
\hline Parity & & $3.00(2.00)$ & & \\
\hline Previous & Yes & & 165 & 47.6 \\
\hline \multicolumn{5}{|l|}{ Contraceptive Use } \\
\hline & No & & 182 & 52.4 \\
\hline $\begin{array}{l}\text { Duration of Hajj } \\
\text { (days) }\end{array}$ & & $44.00(5.40)$ & & \\
\hline $\begin{array}{l}\text { Menstrual Sup- } \\
\text { presion Practice }\end{array}$ & Yes & & 61 & 17.6 \\
\hline & No & & 286 & 82.4 \\
\hline
\end{tabular}

\section{Factors associated with menstrual suppression practice during hajj/pilgrimage}

Bivariate analysis showed that previous use of contraceptives is associated with menstrual suppression practice. The proportion of menstrual suppression practice among ever-users of contraception $(30.0 \%)$ was more compared to never-users of contraception (10.0\%) $(\mathrm{p}<0.001)$. Menstrual suppression practice was not associated with socio-demographic factors or parity. (Refer to Table IV)

\section{DISCUSSION}

This is the first local study on the prevalence of menstrual suppression practice during Hajj. The prevalence of menstrual suppression practice among women pilgrims was $17.6 \%$, which is comparable to the Nigerian study (16.9\%). ${ }^{17}$ Menstrual suppression practice for non-religious reasons was also found to range between 12 to $21 \% .7,8$ This showed that the prevalence of menstrual suppression practice worldwide is similar, despite coming from different backgrounds and different reasons.

Table II: Methods used by women pilgrim during Hajj to suppress menses.

\begin{tabular}{lcc}
\hline $\begin{array}{l}\text { Method used for menstrual } \\
\text { suppression }\end{array}$ & $\boldsymbol{f}$ & $\%$ \\
\hline $30 \mathrm{mcg}$ COCP & 26 & 41.9 \\
$20 \mathrm{mcg}$ COCP & 7 & 11.3 \\
Oral progestogen & 22 & 35.5 \\
Intramuscular Depo Provera & 3 & 4.8 \\
Tranexamic acid & 1 & 1.6 \\
Mefenemic acid & 3 & 4.8 \\
TOTAL & $* 62$ & 100 \\
\hline
\end{tabular}

*one respondent had taken 2 types of NSAID

The low prevalence found in this study could be due to conflicting views from religious authorities regarding menstrual suppression practice during hajj. Some discourage menstrual suppression practice as menstruation is a natural process and the fear that it may cause heavier bleeding than usual and irregular bleeding, which interferes with Haji rites. ${ }^{11}$ Others permit the practice of menstrual suppression, provided that a doctor has approved that it is safe for individual women to do so. ${ }^{14,18}$ This may affect their confidence to attempt menstrual suppression for Hajj.

\section{Methods used for menstrual suppression during Hajj}

Among all methods, COCP was found most popularly used in this study, with around half of women (53.2\%) utilized this method for menstrual suppression during

Table III: Intention to suppress menses duration

\begin{tabular}{lll}
\hline \multirow{2}{*}{ Factors } & \multicolumn{2}{c}{$\begin{array}{r}\text { Intention to suppress } \\
\text { menses durations } \\
\mathbf{N}=\mathbf{6 1}\end{array}$} \\
\cline { 2 - 3 } & $\begin{array}{l}\text { Complete } \\
\mathbf{n}(\mathbf{\%})\end{array}$ & $\begin{array}{l}\text { Partial } \\
\mathbf{n}(\mathbf{\%})\end{array}$ \\
\hline $\begin{array}{l}\text { Method used for } \\
\text { menstrual suppression }\end{array}$ & & \\
COCP & $33(100)$ & $0(0)$ \\
Progestogens (oral) & $12(54.5)$ & $10(45.4)$ \\
Progestogens (IM Depo) & $3(100)$ & $0(0)$ \\
NSAIDS & $0(100)$ & $* 4(100)$ \\
\hline
\end{tabular}


Hajj. COCP was also the method of choice in the Nigerian study. ${ }^{17}$ COCP is among the well-studied drug for menstrual suppression. Usage of extended cycling of COCP had been described since the 1970s where most women reported infrequent menses (82\%), lesser menstrual problems $(20 \%)$, and easier pill-taking (19\%). ${ }^{9}$ Moreover, various randomised control trials and systematic reviews have proven that extended cycling and continuous of COCP is effective, safe, and welltolerated. ${ }^{19-25}$ COCP with higher oestrogen content has better cycle control and lesser unscheduled bleeding compared to lower oestrogen containing COCP. ${ }^{16}$ However, it has higher rates of adverse effects due to the higher oestrogen content.

Table IV: Relationship between selected socio demography and medical characteristic with practice of menstrual suppression among women pilgrim. $(\mathrm{N}=347)$

\begin{tabular}{|c|c|c|c|c|}
\hline \multirow[t]{2}{*}{ Variables } & \multicolumn{2}{|c|}{$\begin{array}{c}\text { Practice Menstrual } \\
\text { Suppression } \\
\mathbf{N}=347 \\
\end{array}$} & \multirow[t]{2}{*}{$\begin{array}{c}\text { Statistical } \\
\text { Test } \\
\text { (df }) \\
\end{array}$} & \multirow[t]{2}{*}{$\begin{array}{c}p- \\
\text { value }\end{array}$} \\
\hline & $\begin{array}{c}\text { Yes } \\
\mathrm{n}=61 \\
\mathrm{n}(\%)\end{array}$ & $\begin{array}{c}\text { No } \\
\mathrm{n}=286 \\
\mathrm{n}(\%)\end{array}$ & & \\
\hline $\begin{array}{l}\text { Age (Years) } \\
\text { Mean SD } \\
\text { Education } \\
\text { Level } \\
\text { Primary }\end{array}$ & $\begin{array}{l}42.21 \\
(6.14)\end{array}$ & $\begin{array}{l}41.94 \\
(6.38)\end{array}$ & $\begin{array}{l}\mathrm{a} 0.230 \\
(345)\end{array}$ & 0.763 \\
\hline Secondary & $12(14.5)$ & $71(85.5)$ & $\mathrm{b} 0.97$ & 0.616 \\
\hline Tertiary & $47(18.4)$ & $\begin{array}{c}209 \\
(81.6)\end{array}$ & & \\
\hline \multicolumn{5}{|l|}{ Occupation } \\
\hline Government & $22(18.2)$ & $99(81.8)$ & & \\
\hline $\begin{array}{l}\text { Private/Self- } \\
\text { Employed }\end{array}$ & $22(18.3)$ & $98(81.7)$ & $\mathrm{b} 0.251$ & 0.882 \\
\hline $\begin{array}{l}\text { Not working/ } \\
\text { Student }\end{array}$ & $17(16.0)$ & $89(84.0)$ & & \\
\hline $\begin{array}{l}\text { Parity (Mead } \\
\text { SD) }\end{array}$ & $3.08(2.00)$ & $\begin{array}{l}2.97 \\
(2.00)\end{array}$ & a $0.40(345)$ & 0.691 \\
\hline $\begin{array}{l}\text { Previous use o } \\
\text { Contraception }\end{array}$ & & & & \\
\hline Yes & $43(26.1)$ & $\begin{array}{c}122 \\
(73.9)\end{array}$ & b15.62 & $<0.001$ \\
\hline No & $18(9.9)$ & $\begin{array}{c}164 \\
(90.1)\end{array}$ & & \\
\hline
\end{tabular}

Progestogens $(35.5 \%)$ were the second commonest method of menstrual suppression in this study. Oral norethisterone $10-20 \mathrm{mg}$ per day is used to stop heavy menstrual bleeding or to regulate bleeding. ${ }^{26}$ Therefore it is used as an alternative to delaying menstruation. However, studies have shown conflicting evidence of its efficacy in inducing amenorrhea. ${ }^{26,27,28}$ It can cause irregular bleeding and spotting in new users, due to the initial shedding of their existing endometrial lining. ${ }^{4}$ However, this is less problematic with short term use to suppress menses during the pilgrimage, and is an alternative for women for whom oestrogen-based methods are not suitable, such as women with migraine or a history of venous thromboembolism.

Intramuscular medroxyprogesterone acetate (Depo Provera) was only used by a minority of women in this study $(4.8 \%)$. It can suppress menstruation for up to 12 14 weeks. The low use of intramuscular medroxyprogesterone acetate among our study populations was not explored. However, the intramuscular route was being less favoured could be due to its late onset of action and delay in the resumption of normal menstrual cycles.

Hormonal methods of menstrual suppression need time to be effective. Women who were late in requesting menstrual suppression were offered tranexamic acid $(4.8 \%)$ and mefenamic acid $(1.6 \%)$ to shortened menstrual flow during Hajj. We did not find any literature describing menstrual suppression using tranexamic acid and mefenamic acid. They reduce menstrual bleeding but do not alter the cycles. ${ }^{15}$

The methods of menstrual suppression were related to the intended duration of menstrual suppression. Hajj duration may range from 15 days to 50 days depending on the type of travel package taken. Most of the women pilgrims in this study took the "muasasah" package group where the duration of hajj is between 40-55 days. In this study, women who took COCP and intramuscular progesterone intended to achieve total amenorrhea throughout Hajj duration, whereas in the oral progestogen group, only about half $(54.5 \%)$ intended for total amenorrhea. Half of those on oral progesterone desired only partial suppression and stopped their oral progesterone once they completed their pillar of Hajj. However, since this study is exploratory, the outcomes of these two groups were not compared. The outcomes of both menstrual suppression methods should be explored in future research. 


\section{Factors Affecting Menstrual Suppression Practice}

This study found that previous usage of contraception was associated with menstrual suppression practice during Hajj. This finding was consistent with the previous study in Nigeria. ${ }^{17}$ This could be due to women who had prior experience of using hormonal contraceptives were possibly more confident to use them for menstrual suppression.

\section{Strength And Limitation of the Study}

This was the first study in our country and region looking at the prevalence of menstrual suppression practice among female Hajj pilgrims. However, due to the limitation of resources and time, only attendees of pre-Hajj courses conducted in 4 centres in the Federal Territory of Kuala Lumpur were included in the study. Recall bias on the menstrual practice via telephone call are potential confounding factors as well. Furthermore, some pilgrims may have opted for private pre-hajj courses and these groups may be missed during the data collections. Therefore, these findings cannot be generalized to the rest of the Malaysian population.

These study findings are a platform for a future study looking into the outcome of the menstrual suppression practice, to explore the reasons for not opting for menstrual suppression, satisfaction in the intended menstrual suppression duration, and the side effect of the preferred method used for menstrual suppression used during Hajj among this group of women which can provide clinical evidence for its usage and address the gap of knowledge that exists in this area. LTH may also consider including discussion about menstrual suppression options in their pre-Hajj courses to cater to those who may be interested to suppress their menstruation.

\section{CONCLUSION}

Nearly one-fifth of female Hajj pilgrims practiced menstrual suppression. COCP and oral progesterone were the preferred methods of contraception. Previous usage of contraception was significantly associated with the success of menstrual suppression. The method chosen corresponds to the desired duration of menstrual suppression. Despite certain limitations, this study produced important baseline knowledge for future female pilgrims and doctors.

\section{CONFLICT OF INTEREST}

None

\section{ACKNOWLEDGEMENT}

This work was supported by UKM Medical Centre Fundamental Research Fund. A special thanks to Tabung Haji (TH) branch of TH Wilayah Persekutuan, TH Kelana Jaya, TH Klang, and TH Bangi for their highest cooperation for participants recruitment at their intensive courses.

\section{DISCLAIMER}

This article's findings had been presented as part of the oral presentation on "Prevalence Study Of Menstrual Suppression Among Malaysian Women Performing Hajj/ Pilgrimage: Its Outcome And Factors Associated With Successful Menstrual Suppression" at The 32nd FIMA Council Meeting and FIMA/IIMA Annual Scientific Meeting 2015 in conjunction with the $8^{\text {th }}$ Mukisi National Meeting Makassar,11-16 August 2015.

\section{REFERENCES}

1. Kitab Bicara Darah Wanita. Edisi Baru bersama Syarabnya - Izalatul Iltibas Syarah Tubfatul A'izza. Disusun oleh Al-Fadbil Al Ustaz Mansoor Bin Ismail Al -Hafiz) ms 744 - 764, Penerbit Mansor bin Ismail. 2017@Mansorbin Ismail ISBN 978-967-14910-0-3

2. Panduan Ibadat Haji Wanita, page 65-67, Bahagian Bimbingan Jabatan Haji, Lembaga Tabung Haji. Terbitan Jawatankuasa Buku Panduan Ibadat Haji Wanita (2013)

3. Nota Kursus Asas Haji page 259-263, Bahagian Bimbingan Jabatan Haji Lembaga Tabung Haji, Terbitan Jawatankuasa Penasihat Ibadah Haji (THJakim) (2017)

4. Hicks, C.W. and Rome, E.S. 2010. Menstrual Manipulation: Options for Suppressing the Cycle. Cleveland Clinic journal of medicine 77(7): 445-453.

5. Hillard, P.A. 2014. Menstrual Suppression: Current Perspectives. International journal of women's health 6: 631. 
6. Bennell, K., White, S. and Crossley, K. 1999. The Oral Contraceptive Pill: A Revolution for Sportswomen? British journal of sports medicine 33(4): 231-238.

7. Powell-Dunford, N.C., Cuda, A.S., Moore, J.L., Crago, M.S., Kelly, A.M. and Deuster, P.A. 2011. Menstrual Suppression for Combat Operations: Advantages of Oral Contraceptive Pills. Women's Health Issues 21(1): 86-91.

8. Johnston-Robledo, I., Ball, M., Lauta, K. and Zekoll, A. 2003. To Bleed or Not to Bleed:Young Women's Attitudes toward Menstrual Suppression. Women \& Health38(3): 59-75.

9. Loudon, N., Foxwell, M., Potts, D., Guild, A. and Short, R. 1977. Acceptability of an Oral Contraceptive That Reduces the Frequency of Menstruation: The Tri-Cycle Pill Regimen. BMJ 2 (6085): 487-490.

10. Al-Kafi\#478 : hukum Jemaah Wanita mengambil pil pencegah haid, rujuk Kasyyaf al-Qina',al-Bahuti (1/2180), 30 November 2016,Web Rasmi Pejabat Mufti Wilayah Persekutuan

11. Nota Kursus Asas Haji, page 255, Bahagian Bimbingan Jabatan Haji Lembaga Tabung Haji, Terbitan Jawatankuasa Penasihat Ibadah Haji (THJakim) (2017),

12. Berita Harian Online, Berita Nasional,Kos Haji Naik 15 peratus, bayaran kekal RM9,980, 7 November 2017)

13. Malaysian 33rd National Muzakarah Haji 2016

14. Nota Kursus Asas Haji page 255-256, Bahagian Bimbingan Jabatan Haji Lembaga Tabung Haji, Terbitan Jawatankuasa Penasihat Ibadah Haji (THJakim) (2017)

15. Bonnar, J. and Sheppard, B.L. 1996. Treatment of Menorrhagia During Menstruation: Randomised Controlled Trial of Ethamsylate, Mefenamic Acid, and Tranexamic Acid. Bmj 313(7057): 579-582.

16. Kaunitz, A.M., Barbieri, R. and Barss, V. 2011. Hormonal Contraception for Suppression of Menstruation. UpToDate.

17. Mohammed-Durosinlorun, A., Raji, H.O., Hussain, N.A., Badmus, S.A. and Ijaiya, M.A. 2012. Menstrual Suppression among Female Nigerian Pilgrims During Hajj. Journal of Family Planning and Reproductive Health Care 38(4): 270 -271 .
18. Panduan Ibadat Haji Wanita, page 74-75, Bahagian Bimbingan Jabatan Haji, Lembaga Tabung Haji. Terbitan Jawatankuasa Buku Panduan Ibadat Haji Wanita (2013).

19. Anderson, F., Hait, H. and Group, S.-S. 2003. A Multicenter, Randomized Study of an Extended Cycle Oral Contraceptive. Contraception 68(2): 8996.

20. Anderson, F., Gibbons, W. and Portman, D. 2006. Long-Term Safety of an Extended- Cycle Oral Contraceptive (Seasonale): A 2-Year Multicenter Open-Label Extension Trial. American journal of obstetrics and gynecology 195(1): 92-96.

21. Archer, D.F., Jensen, J.T., Johnson, J.V., Borisute, H., Grubb, G.S. and Constantine, G.D. 2006.

Evaluation of a Continuous Regimen of Levonorgestrel/Ethinyl Estradiol: Phase 3 Study Results. Contraception 74(6): 439-445.

22. Edelman, A., Gallo, M., Nichols, M., Jensen, J., Schulz, K. and Grimes, D. 2006. Continuous Versus Cyclic Use of Combined Oral Contraceptives for Contraception: Systematic Cochrane Review of Randomized Controlled Trials. Human Reproduction 21(3): 573-578.

23. DiLiberti, C.E., O'Leary, C.M., Hendy, C.H., Waters, D.H. and Margolis, M.B. 2011. SteadyState Pharmacokinetics of an Extended-Regimen Oral Contraceptive with Continuous Estrogen. Contraception 83(1): 55-61.

24. Spencer, A.L. and Bonnema, R. 2011. Health Issues in Oral Contraception: Risks, Side Effects and Health Benefits.

25. Klipping, C., Duijkers, I., Fortier, M.P., Marr, J., Trummer, D. and Elliesen, J. 2012.Contraceptive Efficacy and Tolerability of Ethinylestradiol 20 $\mu \mathrm{g} /$ Drospirenone $3 \mathrm{Mg}$ in a Flexible Extended Regimen: An Open-Label, Multicentre, Randomised, Controlled Study. Journal of Family Planning and Reproductive Health Care 38(2): 7383.

26. Mansour, D. 2012. Safer Prescribing of Therapeutic Norethisterone for Women at Risk of Venous Thromboembolism. Journal of Family Planning and Reproductive Health Care 38(3): 148 $-149$.

27. Mainwaring, R., Hales, H.A., Stevenson, K., Hatasaka, H.H., Poulson, A.M., Jones, K.P. and 
Peterson, C.M. 1995. Metabolic Parameter,

Bleeding, and Weight Changes in Us Women Using

Progestin Only Contraceptives. Contraception 51

(3): 149-153.

28. Shakespeare, J., Neve, E. and Hodder, K. 2000. Is

Norethisterone a Lifestyle Drug? Results of

Database Analysis. BMJ 320(7230): 291 